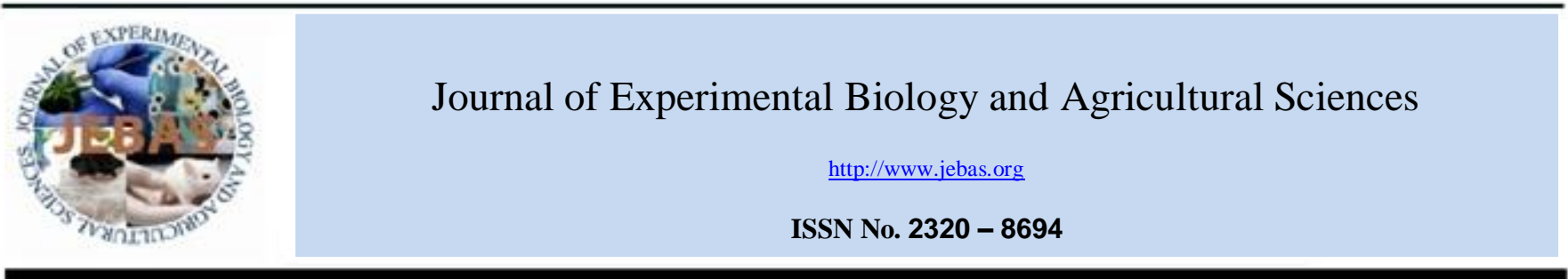

\title{
RAPID ONE STEP PROTOCOL FOR THE in vitro MICRO PROPAGATION OF Morus multicaulis VAR. GOSHOERAMI, AN ELITE MULBERRY VARIETY OF TEMPERATE REGION
}

\author{
Gulab Khan Rohela ${ }^{1 *}$, Aftab Ahmad Shabnam ${ }^{1}$, Pawan Shukla ${ }^{1}$, Azra Nahaid Kamili², \\ Mrinal Kanti Ghosh ${ }^{1}$
}

${ }^{1}$ Central Sericultural Research \& Training Institute, Central Silk Board, Ministry of Textiles, Government of India, Pampore -192 121, Jammu and Kashmir, INDIA.
${ }^{2}$ Department of Environmental Sciences, Centre of Research for Development, University of Kashmir, Hazratbal, Srinagar-190 006, Jammu and Kashmir, INDIA.

Received - October 08, 2018; Revision - November 27, 2018; Accepted - December 12, 2018

Available Online - December 15, 2018

DOI: http://dx.doi.org/10.18006/2018.6(6).936.946

KEYWORDS
Nodal explants
Goshoerami
Micro propagation
Rooting
Hardening
Adventitious callus

\begin{abstract}
Morus multicaulis cv. Goshoerami is the leading mulberry variety for silkworm rearing under temperate climatic conditions of Jammu and Kashmir, India. However, the propagation of this popular mulberry variety has always remained a point of contention due to its poor rooting response through stem cuttings. It normally takes 4 to 5 years for raising the saplings of this variety through conventional root grafting techniques. Therefore, for quick propagation of this poor rooting popular mulberry variety, a one step in vitro protocol was developed by culturing nodal explants from 2 year old plants on Murashige \& Skoog (MS) media supplemented with individual as well as combination of phytohormones. The maximum shoot bud proliferation $(6.3 \pm 0.71 \mathrm{in} \mathrm{cm})$ and rooting $(14.7 \pm 0.53 \mathrm{in} \mathrm{cm})$ was observed when nodal explants were cultured on the combinational media of BAP $(1 \mathrm{mg} / \mathrm{L})$ and IBA $(1 \mathrm{mg} / \mathrm{L})$ after 14 days of culture. These in vitro raised plantlets were hardened by using the sterile soil and vermiculite in 2:1 ratio. Only 25 days were required for the micro propagation and hardening of raised plantlets of Goshoerami through this single step protocol. The hardened plantlets were successfully established in the field with $83 \%$ survival rate. The developed one step protocol can be used efficiently for the mass propagation of this elite mulberry variety throughout the year with in short span of 25 days.
\end{abstract}

* Corresponding author

E-mail: gulab_biotech@yahoo.co.in (Gulab Khan Rohela)

Peer review under responsibility of Journal of Experimental Biology and Agricultural Sciences.

Production and Hosting by Horizon Publisher India [HPI] (http://www.horizonpublisherindia.in/).

All rights reserved.
All the article published by Journal of Experimental Biology and Agricultural Sciences is licensed under a Creative Commons Attribution-NonCommercial 4.0 International License Based on a work at www.jebas.org.

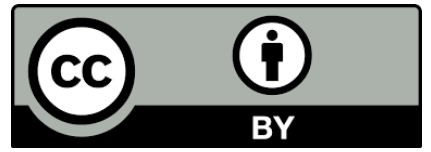




\section{Introduction}

Sericulture is a remunerative industry with most of the benefits going to the rural and poor people across the country i.e. silkworm rearers. Silk is commonly called as the queen of textiles due to its shiny luster, softness, being pleasingly in nature, long durability and having good tensile properties (Rahmathulla, 2012). Among the five types of silks produced in India, the mori silk has a major share in sericulture industry (Datta, 1994). Several factors influences the end product in sericulture i.e. quality cocoon characters. The major factors are quality mulberry leaf, rearing seasons or environmental conditions such as suitable temperature and genetic constitution of silkworm hybrids used (Rahmathulla, 2012).

Mori silkworm is monophagous in nature and feeds only on mulberry leaves (Meneguim et al.,2010) which accounts as the major factor(38\%) in mori silk production (Vijayan et al.,1997a; Vijayan et al., 1997b; Shankar et al.,2001; Srivastava et al.,2006; Vijayan, 2010; Vineet et al., 2012; Gandhi et al., 2012).

Mulberry leaf is not only being used for silk production but it also has several other applications such as feed supplement to several animals (Phinye et al.,2003; Anbarasu et al., 2004; Ba et al., 2005; Martinez et al., 2005; Bakshi \&Wadhwa,2007; Kandylis et al., 2009), several medicinal values, as a protein source (Butt et al., 2008), neuroprotective (Niidome et al., 2007), reduce the symptoms of diabetes (Ewelina et al., 2016), lowering the blood glucose, triglycerides levels in body (Andallu et al., 2001) improvement of skin (Lee et al., 2002; Fang et al., 2005) and for neutralizling the free radicals (Naowaratwattana et al., 2010) etc. Hence Sanchez (2000 \& 2002) described mulberry as exceptional foliage available worldwide and in use for feeding several animal species.

For sericulture, across the country several mulberry varieties were used as superior types in producing quality cocoons. So now-adays, lot of importance is being given to raise and multiply the region and climate wise most suitable mulberry varieties for expanding the sericulture and attracting the farmers in the present dominated era of cereals, pulses, fruits and horticulture crops.

Temperate regions of India with varied agroclimatic conditions (Gani et al., 2016; Aftab et al., 2018) is most suitable for bivoltine type of sericultuiral practices. In Kashmir region, among the various varieties of mulberry Morus multicaulis var. Goshoerami is presently used as one of the elite genotypes in silk production by mori silk worms (Bombyx mori L)(Aftab et al., 2012). M. multicaulis var. Goshoerami has large sized leaves, good canopy, good leaf yield, moisture retention capacity and has the ability to develop into any type of plantation like bush, dwarf or tree type based on requirements. Kour et al. (2015) has recorded the maximum leaf yield of 4.8 tons/ ha during the autumn season from the Goshoerami, further they have concluded to utilize
Goshoerami variety as one of the important genotype for gaining maximum benefit at farmer's level in temperate regions of India. Similarly Shabir et al. (2014) has recorded the maximum leaf lamina length in Goshoerami during spring $(19.75 \mathrm{~cm})$ and autumn $(22.25 \mathrm{~cm})$ seasons, when they evaluated the seventeen temperate mulberry varieties during spring and autumn seasons. They also recorded the highest leaf weight in Goshoerami, out of 17 selected mulberry varieties during spring $(3.11 \mathrm{~g})$ as well as in autumn $(5.03 \mathrm{~g})$ seasons.

The major limiting factor in multiplying the Goshoerami by conventional stem cuttings technique is its poor rooting ability (Aftab et al.,2012, Rohela et al.,2016b). This is mainly due to prevailing cold conditions (Shukla et al., 2016) which in turn decreasing soil temperature and effecting the root formation from the stem cuttings of Goshoerami. In order to induce the roots, the soil temperature has to be increased by using any of the advanced techniques or plantlets have to be produced in in-vitro and controlled conditions.

In vitro propagation techniques have been used extensively since long time for the multiplication of important plant varieties across the world. During the last forty years, several researchers have reported the success in micro propagation of several mulberry varieties from different explants (Thomas, 2002). So, in this present research we are attempting to develop an in vitro micro propagation protocol for propagating the Goshoerami mulberry variety throughout the year in proportionate manner through the rapid and single step based in vitro culture technique with short span of period, instead of multiple steps based in vitro propagation techniques.

\subsection{Materials and methods}

\subsection{Plant Material}

Three years old Goshoerami mulberry variety available in the CSR\&TI, Pampore institute was used as parent plant material in this invitro propagation studies.

\subsection{Surface sterilization}

Nodal segments of 2-3 cm length were collected from the 3 years old M. multicaulis var. Goshoerami plants present in the mulberry fields of CSR\&TI, Pampore institute, Jammu and Kashmir, INDIA. The explants were initially washed for 4-6 times under running tap water followed by washing with tween-20 solution for 3-5 minutes, then treated with $0.5 \%$ Sodium hypochlorite $(\mathrm{NaOCl})$ solution for 3 minutes, $60 \%$ ethanol for 2 minutes and at last treated with $0.1 \%$ Mercuric Chloride $\left(\mathrm{HgCl}_{2}\right)$ for $2-3$ minutes duration. Then the traces of $\mathrm{HgCl}_{2}$ present on surface of explants were removed by rinsing the treated nodal explants in sterile distilled water. 


\subsection{Media preparation and sterilization}

Readymade MS media powder (Murashige \& Skoog 1962) of about 4.42 grams was weighed and dissolved in 1 liter of distilled water, later 30 grams of sucrose $(3 \%)$ was dissolved and the $\mathrm{pH}$ of the MS media was adjusted to $5.5 \pm 0.3$. After adjusting the $\mathrm{pH}$, $0.8 \%$ of agar-agar $(8$ grams $/ 1000 \mathrm{ml})$, a solidifying agent was added and dissolved by slow heating. Now before dispensing the prepared basal MS media into the required culture vessels, appropriate concentrations $(0.5-2.0 \mathrm{mg})$ and combinations of phytohormones (BAP, IAA \& IBA) were added to the prepared MS media. Culture tubes and other culture vessels with prepared MS media containing different concentrations and combinations of phytohormones were sterilized in an autoclave at $121^{\circ} \mathrm{C}$ and $15 \mathrm{lbs}$ pressure for 15 to 20 minutes.

\subsection{Inoculation}

Laminar air flow cabinet is used for providing the aseptic conditions during the inoculation of surface sterilized nodal segments onto MS media with the help of sterile forceps, spirit lamp and sterile tissue paper.

\subsection{Incubation}

The nodal segments inoculated culture tubes and phyta jars were kept in a culture room at $26 \pm 2^{\circ} \mathrm{C}$ under $16 / 8$ hours of light period. Cultures were maintained with the 3000 Lux light intensity under the florescent lamps.

\subsection{Statistical Analysis}

The data obtained during this research study was statistically analyzed by using SPSS Version 17 (SPSS Inc., Chicago, USA) and Tukey's tests at the 5\% level of significance was carried for comparing the mean values. All means are represented with mean \pm SE.

\section{Results}

When the nodal explants of M.multicaulis var. Goshoerami were inoculated onto different concentrations and combinations of phytohormones containing MS media, good responses of complete plantlet formation by simultaneous shoot and root development was observed on combinational media of cytokinins and auxins rather than individual hormones supplemented media. Among different combinations tested, BAP and IBA supplemented MS media has recorded the maximum shoot and root lengths $(\mathrm{cm})$ from the formed complete plantlets.

\subsection{Effect of individual phytohormones}

Initially when nodal explants were inoculated onto individual phytohormones such as BAP, IAA and IBA containing MS media, responses in terms of proliferated shoot length $(\mathrm{cm})$ and root length $(\mathrm{cm})$ were recorded after 7 and 14 days of culture duration (Table 1 \& Figure 1). On individual phytohormones supplemented media, maximum axillary bud proliferation $(2.9 \pm 0.17 \mathrm{~cm})$ was

Table 1 Effect of individual phytohormones supplemented MS media on the nodal explants of Morus multicaulis var. Goshoerami

\begin{tabular}{|c|c|c|c|c|c|c|}
\hline \multicolumn{3}{|c|}{ Plant Growth Regulators in $\mathrm{mg} / \mathrm{L}$} & \multicolumn{2}{|c|}{$\begin{array}{l}\text { Proliferated axillary shoot length in } \mathrm{cms} \\
\qquad(\mathrm{X} * \pm \text { S.E })\end{array}$} & \multicolumn{2}{|c|}{$\begin{array}{c}\text { Root length in cms } \\
\left(X^{*} \pm \text { S.E }\right)\end{array}$} \\
\hline BAP & IAA & IBA & After 7 days of culture & After 14 days of culture & $\begin{array}{l}\text { After } 7 \text { days of } \\
\text { culture }\end{array}$ & $\begin{array}{c}\text { After 14days of } \\
\text { culture }\end{array}$ \\
\hline 0.5 & - & - & \multirow{3}{*}{$\begin{array}{l}1.0 \pm 0.16^{\mathrm{c}} \\
2.4 \pm 0.31^{\mathrm{e}} \\
2.6 \pm 0.17^{\mathrm{f}}\end{array}$} & $1.6 \pm 0.22^{b}$ & - & - \\
\hline 1.0 & - & - & & $2.9 \pm 0.17^{\mathrm{d}}$ & - & - \\
\hline 1.5 & - & - & & $4.8 \pm 0.34^{\mathrm{e}}$ & - & - \\
\hline 2.0 & - & - & $1.2 \pm 0.46^{\mathrm{c}}$ & $2.4 \pm 0.36^{\mathrm{d}}$ & - & - \\
\hline- & 0.5 & - & \multirow{3}{*}{$\begin{array}{l}0.7 \pm 0.10^{\mathrm{b}} \\
1.6 \pm 0.06^{\mathrm{a}} \\
0.4 \pm 0.09^{\mathrm{a}}\end{array}$} & $1.0 \pm 0.40^{\mathrm{b}}$ & - & $0.3 \pm 0.02^{\mathrm{a}}$ \\
\hline- & 1.0 & - & & $2.2 \pm 0.38^{\mathrm{c}}$ & $0.4 \pm 0.16^{\mathrm{b}}$ & $2.1 \pm 0.85^{\mathrm{d}}$ \\
\hline- & 1.5 & - & & $1.9 \pm 0.12^{\mathrm{b}}$ & - & $1.3 \pm 0.63^{\mathrm{c}}$ \\
\hline- & 2.0 & - & $0.6 \pm 0.19^{\mathrm{a}}$ & $1.8 \pm 0.24^{\mathrm{b}}$ & - & - \\
\hline- & - & 0.5 & \multirow{3}{*}{$\begin{array}{l}0.3 \pm 0.11^{\mathrm{a}} \\
0.6 \pm 0.43^{\mathrm{a}} \\
1.0 \pm 0.23^{\mathrm{b}}\end{array}$} & $1.1 \pm 0.31^{\mathrm{b}}$ & - & $0.6 \pm 0.13^{b}$ \\
\hline- & - & 1.0 & & $0.9 \pm 0.16^{\mathrm{b}}$ & $0.3 \pm 0.03^{\mathrm{b}}$ & $7.2 \pm 0.68^{\mathrm{e}}$ \\
\hline- & - & 1.5 & & $1.7 \pm 0.32^{\mathrm{d}}$ & $0.1 \pm 0.15^{\mathrm{a}}$ & $1.8 \pm 0.64^{\mathrm{c}}$ \\
\hline- & - & 2.0 & $0.5 \pm 0.08^{\mathrm{a}}$ & $1.3 \pm 0.46^{\mathrm{b}}$ & - & $0.2 \pm 0.07^{\mathrm{a}}$ \\
\hline
\end{tabular}

BAP: 6-Benzylaminopurine; IAA: Indole-3-Acetic Acid; IBA: Indole-3-Butyric Acid;

*: Mean of 10 replications and SE: Standard Error

Means \pm SE followed by same letters are not significantly different at $\mathrm{P}=0.05$ according to SPSS Version 17 (SPSS Inc., Chicago, USA) and means were compared using Tukey's tests at the $5 \%$ level of significance 


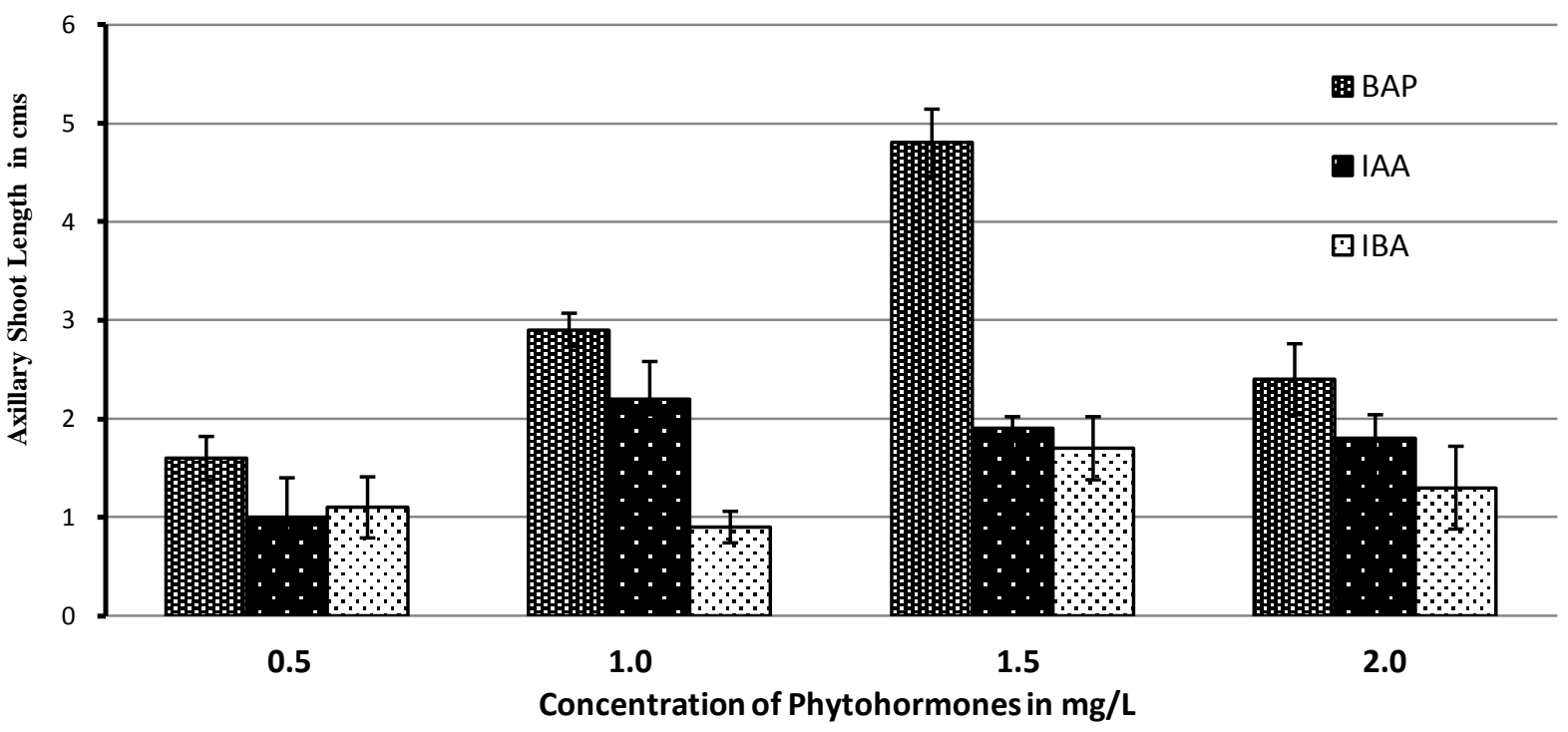

Figure 1 Effect of individual phytohormones supplemented MS media on the nodal explants of Morus multicaulis var. Goshoerami after 14 days of culture.

observed from nodal explants cultured on MS media supplemented with $1.0 \mathrm{mg} / \mathrm{L}$ concentration of BAP (Table 1 ).

On different concentrations of BAP $(0.5,1.0,1.5 \& 2.0 \mathrm{mg} / \mathrm{L})$ supplemented media, axillary bud proliferation responses were recorded after 14 days of culture. On IAA supplemented media, even though both shoot and root developments were observed from nodal explants, the response of shoot development is slow whereas root development is fast. At lower concentrations of IAA $(1.0 \mathrm{mg} / \mathrm{L})$, minimal shoot growth $(1.6 \pm 0.06 \mathrm{~cm})$ and root growth $(0.4 \pm 0.16 \mathrm{~cm})$ responses was observed after 7 days of culture (Figure 3A), but when results were recorded after 14 days of

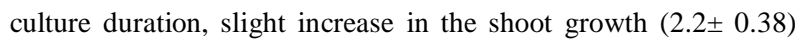
and enhanced root growth $(2.1 \pm 0.85)$ responses (Figure $3 \mathrm{~B}$ ) were observed (Table 1). The above results were clearly indicating that on IAA (1.0 mg/L) supplemented media, the shoot growth is slow and root growth is faster.

At higher concentrations of IAA $(2.0 \mathrm{mg} / \mathrm{L})$, along with axillary bud proliferation adventitious roots were formed from the nodal explants exactly at the place where the earlier petiole has fallen off from the inoculated nodal explants (Figure 3C). This result was observed repeatedly from nodal explants on IAA $(2.0 \mathrm{mg} / \mathrm{L})$ supplemented media. Further, in case of root formation, at individual phytohormones supplemented media, maximum root growth $(7.2 \pm 0.68 \mathrm{~cm})$ was observed on IBA $(1.0 \mathrm{mg} / \mathrm{L})$ supplemented media after 14 days of culture (Table 1).

\subsection{Effect of combinational phytohormones}

On individual phytohormones supplemented media, as maximum shoot growth $(2.9 \pm 0.17 \mathrm{~cm})$ was observed on MS media supplemented with $1.0 \mathrm{mg} / \mathrm{L} \mathrm{BAP}$, this concentration of BAP was taken as constant and combined with different concentration of either IAA or IBA while preparing combinations of phytohormones supplemented media (Table 2). Slow growth was recorded on the combinational media of BAP (1.0) and IBA at lower concentrations. Minimal axillary bud proliferation $(0.8 \pm 0.23 \mathrm{~cm})$ and root growth $(2.4 \pm 0.15 \mathrm{~cm})$ was observed from nodal explants of Goshoerami on MS media supplemented with BAP $(1 \mathrm{mg} / \mathrm{L})$ and IBA $(0.5 \mathrm{mg} / \mathrm{L})$ after 14 days of culture (Figure 5A, 5B and 5C).

Overall, when nodal explants were cultured on different concentrations and combinations of phytohormones supplemented media, the maximum axillary bud proliferation or shoot growth $(6.3 \pm 0.71)$ (Figure $5 \mathrm{~F}$ ) and root growth (14.7 \pm 0.53 ) (Figure $5 \mathrm{G}$ ) was observed on combinational media of BAP $(1.0 \mathrm{mg} / \mathrm{L})$ and IBA $(1.0 \mathrm{mg} / \mathrm{L})$ (Figure 4$)$ after 14 days of culture. Initially after 7 days of culture the initiated roots were white, but after 14 days of culture, the developed roots turned brown in color, similar observation was also made by Sajeevan et al., (2011) for in vitro raised V1 mulberry plantlets. The turning of in vitro induced roots into brown color is majorly due to the nature of phenolic compounds produced by the root system of tree species (Rohela et al., 2016a). 
Table 2 Effect of Combination of phytohormones supplemented MS media on the nodal explants of Morus multicaulis var. Goshoerami

\begin{tabular}{|c|c|c|c|c|c|c|}
\hline \multicolumn{3}{|c|}{ Plant Growth Regulators in mg/L } & \multicolumn{2}{|c|}{$\begin{array}{l}\text { Proliferated axillary shoot length in } \mathrm{cms} \\
\qquad\left(X^{*} \pm \text { S.E }\right)\end{array}$} & \multicolumn{2}{|c|}{$\begin{array}{c}\text { Root length in cms } \\
\left(X^{*} \pm \text { S.E }\right)\end{array}$} \\
\hline BAP & IAA & IBA & After 7 days of culture & $\begin{array}{l}\text { After 14days of } \\
\text { culture }\end{array}$ & $\begin{array}{l}\text { After } 7 \text { days of } \\
\text { culture }\end{array}$ & $\begin{array}{l}\text { After 14days of } \\
\text { culture }\end{array}$ \\
\hline 1.0 & 0.5 & - & $0.8 \pm 0.13^{\mathrm{b}}$ & $1.4 \pm 0.20^{\mathrm{b}}$ & $0.6 \pm 0.13^{\mathrm{a}}$ & $1.3 \pm 0.20^{\mathrm{b}}$ \\
\hline 1.0 & 1.0 & - & $2.2 \pm 0.26^{\mathrm{e}}$ & $2.8 \pm 0.31^{\mathrm{d}}$ & $1.2 \pm 0.58^{\mathrm{b}}$ & $6.9 \pm 0.32^{\mathrm{g}}$ \\
\hline 1.0 & 1.5 & - & $1.6 \pm 0.14^{\mathrm{d}}$ & $2.1 \pm 0.18^{c}$ & $1.8 \pm 0.64^{\mathrm{c}}$ & $4.3 \pm 0.41^{\mathrm{e}}$ \\
\hline 1.0 & 2.0 & - & $0.7 \pm 0.31^{\mathrm{b}}$ & $0.9 \pm 0.26^{\mathrm{a}}$ & - & - \\
\hline 1.0 & - & 0.5 & $0.4 \pm 0.33^{\mathrm{a}}$ & $0.8 \pm 0.23^{\mathrm{a}}$ & $0.7 \pm 0.16^{\mathrm{a}}$ & $2.4 \pm 0.15^{\mathrm{c}}$ \\
\hline 1.0 & - & 1.0 & $2.8 \pm 0.34^{\mathrm{d}}$ & $6.3 \pm 0.71^{\mathrm{c}}$ & $2.1 \pm 0.49^{\mathrm{d}}$ & $14.7 \pm 0.53^{\mathrm{h}}$ \\
\hline 1.0 & - & 1.5 & $0.9 \pm 0.46^{\mathrm{b}}$ & $4.2 \pm 0.63^{\mathrm{b}}$ & $2.0 \pm 0.45^{\mathrm{d}}$ & $10.6 \pm 0.67^{f}$ \\
\hline 1.0 & - & 2.0 & $1.2 \pm 0.17^{\mathrm{c}}$ & $1.7 \pm 0.41^{\mathrm{b}}$ & $0.6 \pm 0.31^{\mathrm{a}}$ & $4.2 \pm 0.19^{\mathrm{d}}$ \\
\hline
\end{tabular}

BAP: 6-Benzylaminopurine; IAA: Indole-3-Acetic Acid; IBA: Indole-3-Butyric Acid;

*: Mean of 10 replications and SE: Standard Error

Means \pm SE followed by same letters are not significantly different at P=0.05 according to SPSS Version 17 (SPSS Inc., Chicago, USA) and means were compared using Tukey's tests at the $5 \%$ level of significance.

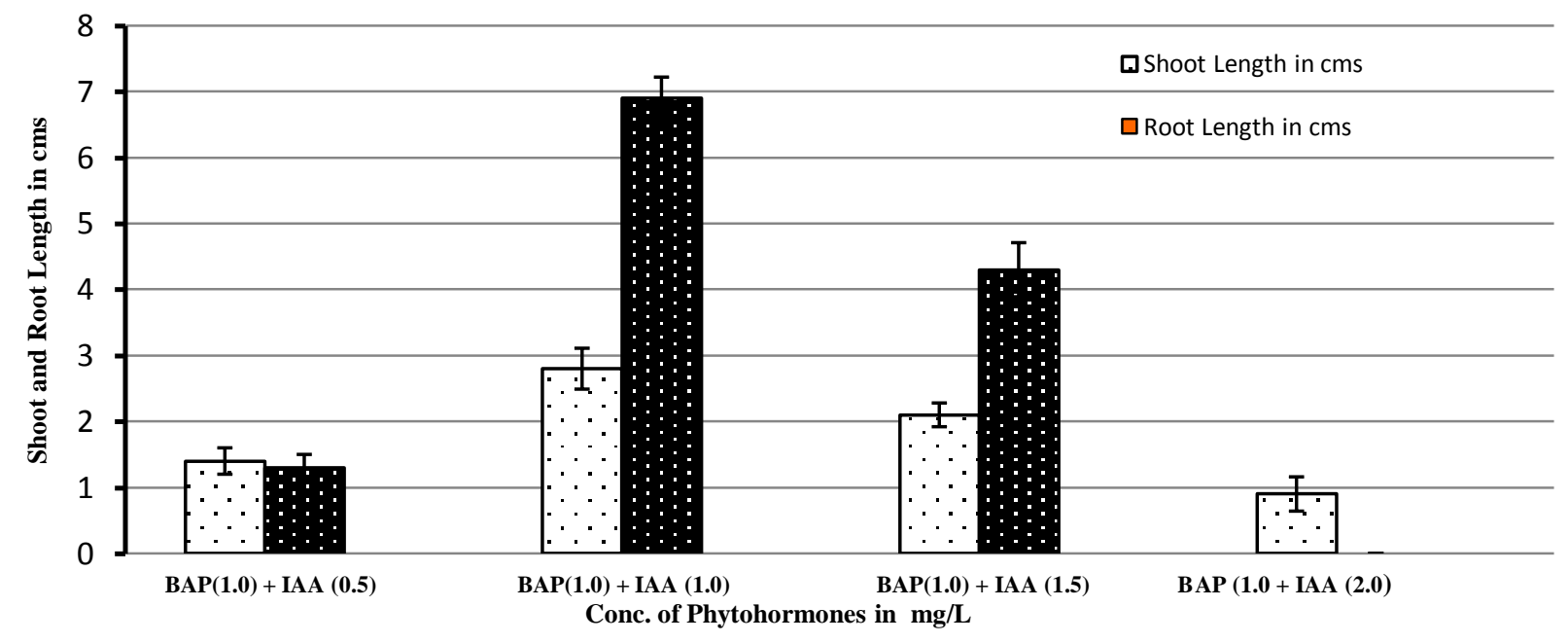

Figure 2 Effect of combination of BAP and IAA supplemented MS media on the nodal explants of Morus multicaulis var. Goshoerami after 14 days of culture.

On another combination of BAP(1.0) and IAA $(0.5,1.0,1.5 \& 2.0$ $\mathrm{mg} / \mathrm{L}$ ) supplemented media, even though both the axillary bud proliferation and root initiation was observed after 14 days of culture (Figure 2), but the results were not comparable to that of BAP and IBA supplemented media. On combination of BAP (1 $\mathrm{mg} / \mathrm{L})$ and IAA (2 $\mathrm{mg} / \mathrm{L})$ supplemented media along with axillary bud proliferation $(0.9 \pm 0.26)$, adventitious callus was also formed from the internodal regions of nodal explants after 14 days of culture (Figure 3D).

\subsection{Hardening and acclimatization}

Developed in vitro plantlets were hardened by using the sterile soil and vermiculite in 2:1 ratio (Figure 5D). Totally 25 days were required for the micro propagation and hardening of raised plantlets of M. multicaulis var. Goshoerami through this single step protocol. The hardened plants were initially kept in cups (Figure 5E) and pots (Figure 5H) for two months duration and maintained in culture room and then transferred into the field 

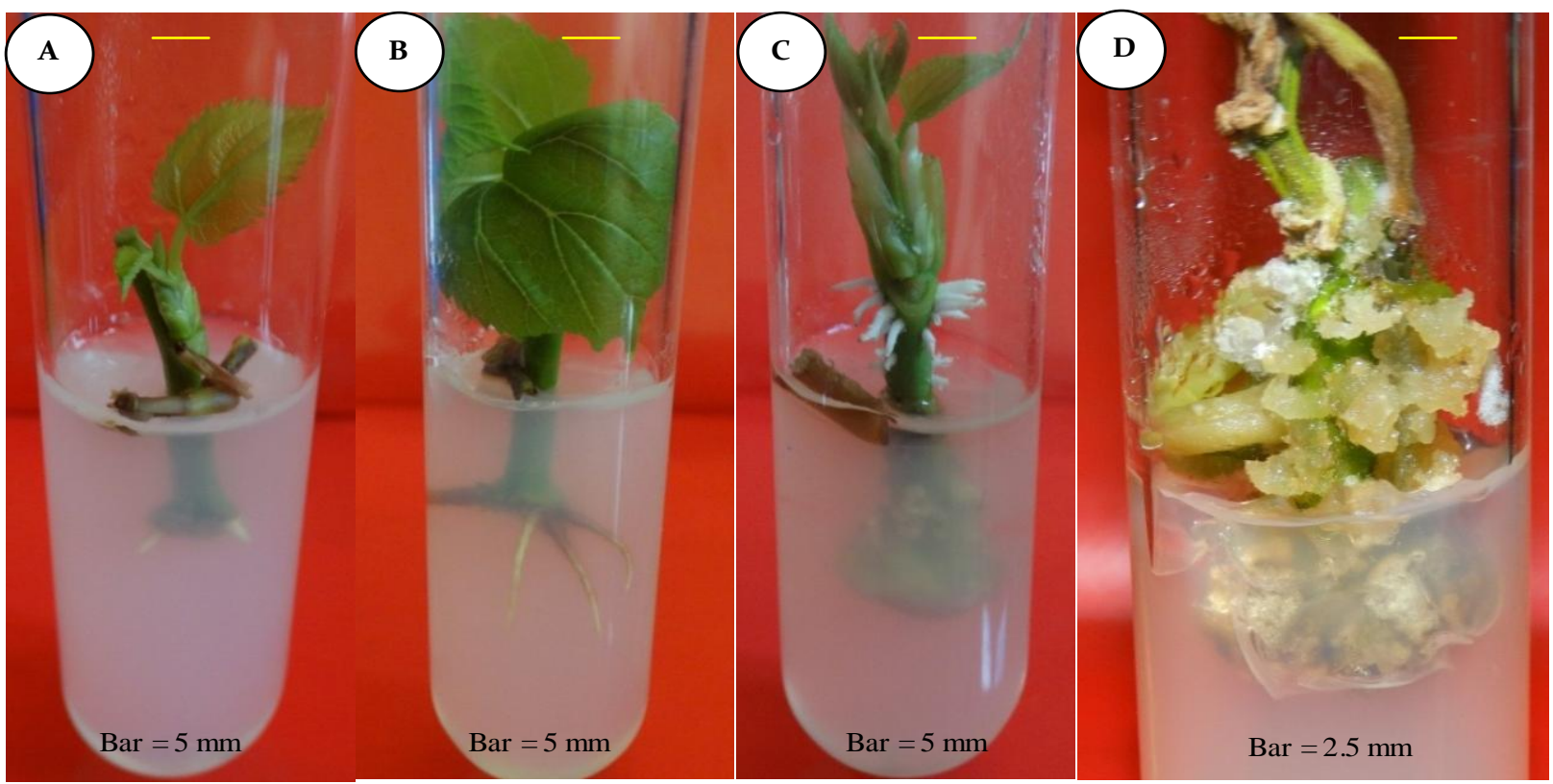

Figure 3 Micro propagation of Morus multicaulis var. Goshoerami by using nodal explants

A) Axillary bud proliferation $(1.6 \mathrm{~cm})$ and induction of roots $(0.4 \mathrm{~cm})$ from nodal explants of Morus Multicaulis var. Goshoerami on MS media supplemented with IAA $(1.0 \mathrm{mg} / \mathrm{L})$ after 7 days of culture.

B) Shoot Growth $(2.2 \mathrm{~cm})$ and Root Growth $(2.1 \mathrm{~cm})$ from nodal explants of Morus Multicaulis var. Goshoerami on MS media supplemented with IAA ( $1 \mathrm{mg} / \mathrm{L})$ after 14 days of culture.

C) Initiation of adventitious roots from nodal segments on IAA $(2.0 \mathrm{mg} / \mathrm{L})$ supplemented media.

D) Callus induction from the internodal regions of Goshoerami on MS media supplemented with BAP (1 mg/L) and IAA (2 mg/L).

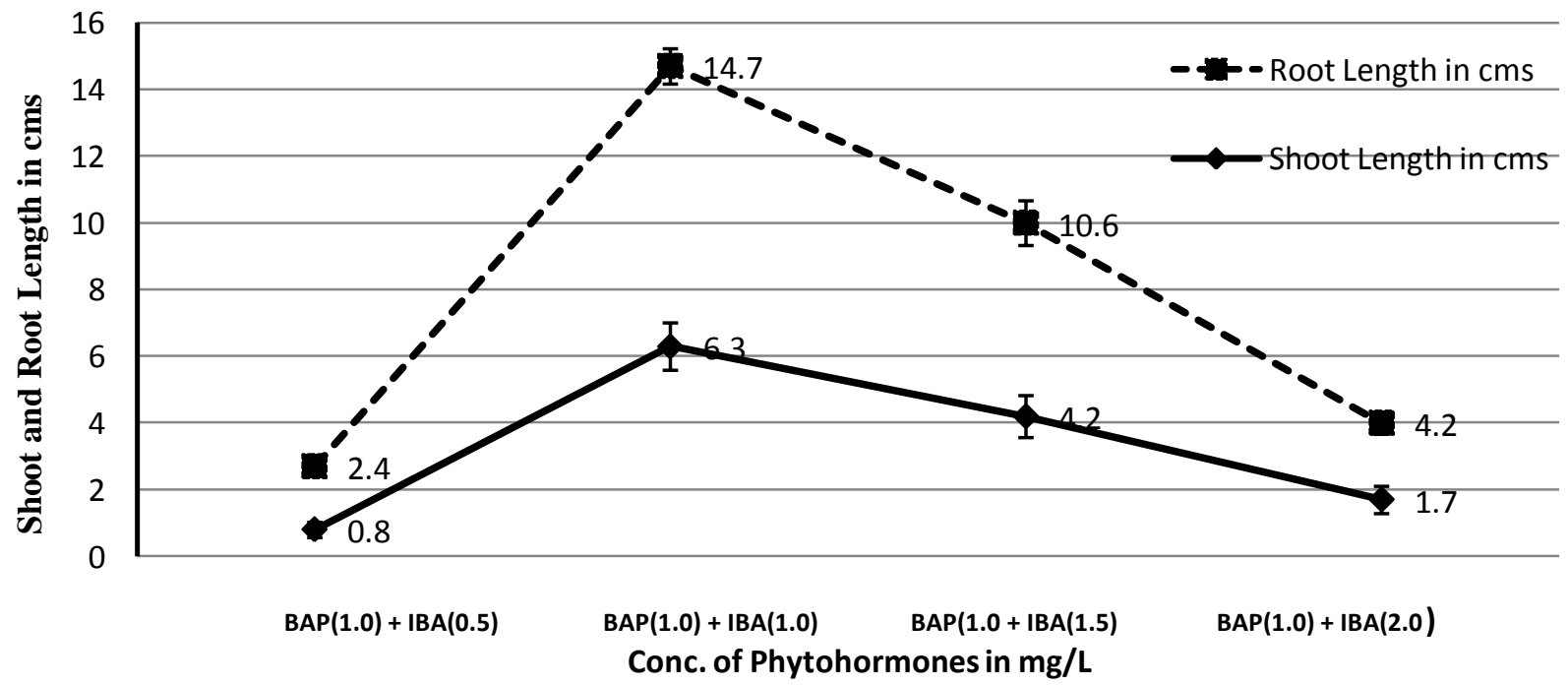

Figure 4 Effect of combination of BAP and IBA supplemented MS media on the nodal explants of Morus multicaulis var. Goshoerami after 14 days of culture. 


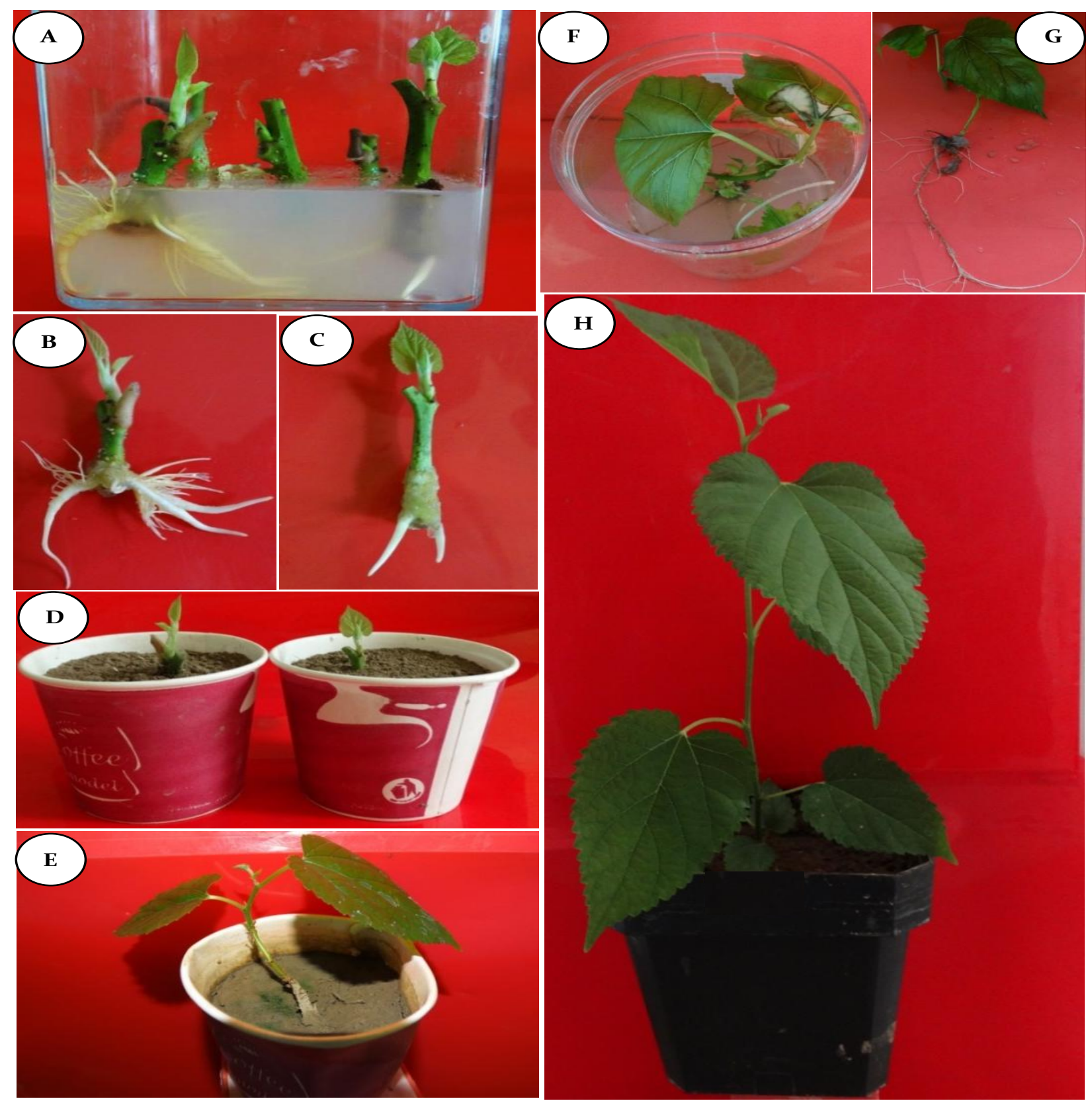

Figure 5 Micro propagation of Morus multicaulis var. Goshoerami by using nodal explants

A) Axillary bud proliferation $(0.8 \mathrm{~cm})$ and induction of roots $(2.4 \mathrm{~cm})$ from nodal explants of Morus Multicaulis var. Goshoerami on MS media supplemented with BAP $(1 \mathrm{mg} / \mathrm{L})$ and IBA $(0.5 \mathrm{mg} / \mathrm{L})$ after 14 days of culture.

B) Complete plantlet of Goshoerami with well-developed root system

C) Complete plantlet of Goshoerami with few developed roots

D) Hardening of in vitro raised Goshoerami plantlets

E) Hardened plantlet of Goshoerami in a poly cup by using the sterile soil and vermiculite in 2:1 ratio.

F) Complete plantlet of Goshoerami with well-formed axillary shoot $(6.3 \mathrm{~cm})$ and root system $(14.7 \mathrm{~cm})$ developed from nodal explants cultured on the combinational media of BAP

$(1 \mathrm{mg} / \mathrm{L})$ and IBA $(1 \mathrm{mg} / \mathrm{L})$ after 14 days of culture

G) Separated plantlet of Goshoerami for hardening process with well-developed root system

H) Hardened plantlet of Goshoerami (2 months old) in a plastic pot after hardening process with the sterile soil and vermiculite in 2:1 ratio

Journal of Experimental Biology and Agricultural Sciences http://www.jebas.org 
conditions after gradually increasing the temperature from $27^{\circ} \mathrm{C}$ to as per the field conditions. The hardened plantlets were successfully established in the field with $83 \%$ survival rate.

\section{Discussions}

In present study, good response in terms of axillary bud proliferation and shoot growth from nodal explants of $M$. multicaulis var. Goshoerami was obtained on MS media supplemented with BAP hormone. Chitra \& Padmaja (1999) also reported the similar results; they achieved maximum shoot growth from nodal explants of $M$. indica cultivar M5 by using BAP (0.5 $1.0 \mathrm{mg} / \mathrm{L}$ ) as the main phytohomorne supplemented with MS media. Raghunath et al. (2013) and Vijayan et al. (2000) has reported mulberry leaf as explant and BAP as the hormone for micro propagation of M.indica cv. V1. Cytokinin, BAP (6Benzylaminopurine) was also reported as the main plant growth regulator in micro propagation of several other plants species. Sujatha et al. (2013) obtained maximum number of plantlets in sponge gourd (Luffacy lindrica) by using leaf and nodal explants at $1.5 \mathrm{mg} / \mathrm{L}$ concentration of BAP. Similarly on individually supplemented BAP (Rohela et al., 2018b) and in combinations of BAP with TDZ (Thiadiazuron) (Rohela et al., 2013; Rohela et al., 2015; Rohela et al., 2016c; Korra et al., 2017; Rohela et al., 2018a) of multiple shoots were regenerated from nodal explants, shoot tip explants, leaf and stem based calluses of Rauwolfia tetraphylla and Morus Sps.

In mulberry, several researchers have reported the clonal propagation of mulberry plantlets by using nodal segments (Bapat \& Rao,1990; Pattnaik \& Chand,1997; Chitra\& Padmaja, 2001; Anis et al.,2003) as explants and BAP as the plant growth regulator. But, all these earlier reporters have used nodal explants and carried out micro propagation of mulberry plantlets by two step protocol, where initially axillary bud proliferation was carried on a shoot medium and later the proliferated axillary shoots were excised and transferred onto rooting media for root initiation. Whereas in present study, we have successfully carried out in vitromicropropagationof M.multicaulis var. Goshoerami by a rapid and single step protocol. Through this research study, we reported the simultaneous shoot and root development from the nodal segments of M.multicaulis var. Goshoerami in a single step on the MS media supplemented with different combinations and concentrations of cytokinins and auxins.

Similarly, one step protocol was also reported for the micro propagation of several other plant species, such as Vaccinium macrocarpon (Debnath \& Mc Rae, 2005; Debnath, 2008), Bacopa monnieri (Naik et al., 2014), Stevia rebaudiana bertoni (Peixe et al.,2015), Lilium martagon var. cattaniae (Marijana et al., 2012), Bambusa balcooa Roxb. (Beena et al., 2015), Cicer arietinum
(Sujatha et al., 2007), Malus domestica (Bommineni et al., 2001), and Aloe vera (Dwivedi et al., 2014).

Out of several concentrations and combinations of phytohormones tested in this study, the combination of BAP and IBA has given better results. Overall the maximum shoot bud proliferation $(6.3 \pm$ 0.71 in $\mathrm{cm})$ and best rooting $(14.7 \pm 0.53$ in $\mathrm{cm})$ was observed when nodal explants were cultured on the combinational media of BAP $(1 \mathrm{mg} / \mathrm{L})$ and IBA $(1 \mathrm{mg} / \mathrm{L})$ after 14 days of culture. Cytokinin and auxin combination of BAP and IBA were used earlier for the micro propagation of several other plant species such as Musa sp. (Ikram-ul-haq \& Dahot, 2007; Buah et al., 2010), Strelitzia reginae (North et al., 2012) and Melia azedarach (Silvia et al., 2002).

\section{Conclusion}

The developed rapid one step protocol could be used efficiently for the in vitro micro propagation of an elite temperate mulberry variety $M$. multicaulis var. Goshoerami within the short duration of 25- 40 days to that of 60-80 days duration of routinely carried multiple steps based in vitro culture techniques. Also the long duration of raising the Goshoerami mulberry saplings through conventional techniques can be drastically reduced if the winter dormancy period of temperate region can be utilized for the developed rapid one step in vitro propagation protocol along with green house phase of acclimatizing the raised plantlets to field conditions.

\section{Acknowledgements}

Authors thank Central Silk Board, Ministry of Textiles, Government of India for providing financial support under project code PIB:3571. Authors also thank Director, Central Sericultural Research \& Training Institute, Pampore (J\&K), INDIA for providing all the necessary facilities in carrying out this research work.

\section{Conflict of interest}

All the authors declare that there is no conflict of interest

\section{References}

Aftab AS, Fotadar RK, Anil D, Bhat AH (2012) A comparative analysis of tropical and temperate genotypes and behaviour of five species of mulberry under temperate conditions of Kashmir. Research Journal of Agricultural Sciences 3 : 089-093.

Aftab AS, Chauhan SS, Gulab K, Pawan S, Saini P, Ghosh MK(2018) Mulberry breeding strategies for North and North West India. International Journal of Advances Research in Science and Engineering 7: 2124-2133. 
Anbarasu C, Dutta N, Sharma K, Rawat M(2004) Response of goats to partial replacement of dietary protein by a leaf meal mixture containing Leucaena leucocephala, Morus alba and Tectona grandis. Small Ruminant Research 51 : 47-56. doi: http://dx.doi.org/10.1016/S0921-4488(03)00203-7.

Andallu B, Suryakantham V, Lakshmi SB, Kesava Reddy G (2001) Effect of mulberry (Morus indica L.) therapy on plasma and erythrocyte membrane lipids in patients with type 2 diabetes. Clinica Chemica Acta 314 : 47-53. PMID:11718678.

Anis M, Faisal M, Singh SK (2003) Micropropagation of mulberry (Morus alba L.) through in vitro culture of shoot tip and nodal explants. Plant Cell Tissue \& Organ Culture 13: 47 - 51.

Ba NX, Giang VD, Ngoan LD(2005) Ensiling of mulberry foliage (Morus alba) and the nutritive value of mulberry foliage silage for goats in central Vietnam. Livestock Research for Rural Development $17: 1-8$

Bakshi MPS, Wadhwa M (2007) Tree leaves as complete feed for goat bucks. Small Ruminant Research 69 : 74-78.

Bapat VA, Rao PS (1990) In vitro growth of encapsulated axillary buds of mulberry (Morus indica L.). Plant Cell Tissue \& Organ Culture 20:69-70. doi: 10.1007/BF00034760.

Beena P, Bharat G, Nisha P, Vipul B(2015) One step prehardening micropropagation of Bambusa balcooa Roxb. Journal of Phytology 7:1-9. doi: 10.5455/jp.2015-06-02 .

Bommineni VR, Mathews H, Samuel SB, Kramer M, Wagner DR (2001) A new method for rapid in vitro propagation of Apple and Pear. Horticultural Science 36 : 1102-1106.

Buah JN, Danso E, Taah KJ, Abole EA, Bediako EA, Asiedu J, Baidoo R (2010) The effects of different concentrations cytokinins on the in vitro multiplication of Plantain (Musa sp.). $\begin{array}{lllll}\text { Biotechnology } & 9 & \text { : } & 343-347 . & \text { DOI: }\end{array}$ http://dx.doi.org/10.3923/biotech.2010.343.347.

Butt MS, Nazir A, Sultan TS, Schroen K (2008) Morus alba L. nature's functional tonic. Trends in Food science and technology 19:505-512.

Chitra DSV, Padmaja G (1999) Clonal propagation of mulberry (Morus indica L. Cult. M-5) through in vitro culture of nodal explants. Scientia Horticulturae 80: 289-298. DOI: http://dx.doi.org/10.1016/S0304-4238(98)00252-0.

Chitra DSV, Padmaja G (2001) Seasonal influence on axillary bud sprouting and micropropagation of elite cultivars of mulberry. Scientia Horticulturae 92:55-68.
Datta RK (1994) Production and Demand of Silk in India, In Global Silk Scenario-2000, Proceedings of the International Conference on Sericulture. Oxford, IBM, 44-54.

Debnath SC (2008) Zeatin-induced one-step in vitro cloning affects the vegetative growth of cranberry (Vaccinium macrocarpon Ait.) micropropagules over stem cuttings. Plant Cell, Tissue and Organ Culture 93 : 231-240. doi: $10.1007 / \mathrm{s} 11240-008-9366-0$.

Debnath SC, McRae KB (2005) A one-step in vitro cloning procedure for cranberry (Vaccinium macrocarpon Ait.): the influence of cytokinins on shoot proliferation and rooting. Small Fruits Review 4: 57-75. doi: 10.1007/BF02788801.

Dwivedi NK, Indiradevi A, Suma A, Asokan NR (2014) Rapid in vitro micropropagation of non-bitter vegetable type Aloe vera L. (IC333202). Research in Plant Biology 4 : 39-43, 2014.

Ewelina K, Magdalena JS, Zbigniew K, Ewa F, Rafal WW (2016) The effects of supplementary mulberry leaf (Morus alba) extracts on the trace element status $(\mathrm{Fe}, \mathrm{Zn}$ and $\mathrm{Cu})$ in relation to diabetes management and antioxidant indices in diabetic rats. Biological Trace Element Research 174 : 158-165. doi: 10.1007/s12011-016-0696-1.

Fang SH, Hou YC, Chao PD (2005) Pharmacokinetic and pharmacodynamic interactions of morin and cyclosporine. Toxicology and Applied Pharmacology 205: 65-70.

Gandhi DS, Chakraborti SP, Roychowdhuri S, Das NK, Vijayan K, Ghosh PD (2012) Development of mulberry varieties for sustainable growth and leaf yield in temperate and subtropical regions of India. Euphytica 185 : 215-225. doi: 10.1007/s10681-011-0523-x.

Gani M, Gupta RK, Kaul V, Zargar SM, Bali K, Khan G (2016) Management of the Tent Caterpillar (Malacosoma indicum) Using Nucleopolyhedrovirus in Jammu \& Kashmir, India, in: Materials Today: Proceedings. Elsevier Ltd, Pp. 3914-3924 doi:10.1016/j.matpr.2016.11.049.

Ikram-ul-Haq, Dahot MU (2007) Morpho-physiological aspects of micro-propagating banana under different hormonal conditions. Asian Journal of Plant Sciences 6 : 496-501. DOI: http://dx.doi.org/10.3923/ajps.2007.496.501.

Kandylis K, Hadjigeorgiou I, Harizanis P (2009) The nutritive value of mulberry leaves (Morus alba) as a feed supplement for sheep. Tropical Animal Health Production 41 : 17-24. doi: 10.1007/s11250-008-9149-y. 
Korra R, Bylla P, Rohela GK, Pendli S, Reuben TC (2017) In vitro micro propagation and confirmation of genetic fidelity using RAPD marker in ethno medicinal plant Stachytarpheta jamaicensis L. Vahl. International Journal of Advanced Research 5: 1494-1502. DOI: http://dx.doi.org/10.21474/IJAR01/4862.

Kour R, Rathore MS, Srinivasulu Y, Sahaf KA (2015) Evaluation of Five improved mulberry Genotypes as trees under different locations in Kashmir. Indian Horticultural Journal 2 : 91-94.

Lee SH, Choi SY, Kim H, Hwang J S, Lee BG, Gao JJ, Kim SY (2002) Mulberroside F isolated from the leaves of Morus alba inhibits melanin biosynthesis. Biological and Pharmaceutical Bulletin 25:1045-1048.

Marijana S, Suzana Z, Jelena S, Branislav S, Aneta S, Sladjana T, Dragoljub G (2012) Efficient one-step tissue culture protocol for propagation of endemic plant, Lilium martagon var. cattaniae Vis. African Journal of Biotechnology 11 :1862-1867. doi: 10.5897/AJB11.2076.

Martinez M, Motta W, Cervera C, Pla M (2005) Feeding mulberry leaves to fattening rabbits: effects on growth, carcass characteristics and meat quality. Animal Science 80 : 275-280. doi: https://doi.org/10.1079/ASC41110275.

Meneguim AM, Lustri C, Oliveira DD, Yada IFU, Pasini A (2010) Bromatological characterization of mulberry cultivars, Morus spp., and determination of nutritional indexes of Bombyx mori L. (Lepidoptera: Bombycidae). Neotropical Entomology 39: 506-512.

Murashige T, Skoog F (1962) A revised medium for rapid growth and bioassay with tobacco tissue cultures. Plant Physiology 15: 473-497. DOI: http://dx.doi.org/10.1111/j.13993054.1962.tb08052.x.

Naik PM, Patil BR, Kotahi KS, Kazi AM, Lokesh H, Kamplikoppa SG (2014) Rapid one step protocol for in vitro regeneration of Bacopa monnieri (L.). Journal of Cell \& Tissue Research 14 :4293-4296.

Naowaratwattana W, De-Eknamkul W, De Mejia EG (2010) Phenolic-containing organic extracts of mulberry (Morus alba L.) leaves inhibit HepG2 hepatoma cells through G2/M phase arrest and inhibition of topoisomerase II $\alpha$ activity. Journal of Medicinal Food $13: 045-1056$.

Niidome T, Takahashi K, Goto Y, Goh SM, Tanaka N, Kamei K, Ichida M, Hara S, Akaike A, Kihara T, Sugimoto H (2007) Mulberry leaf extract prevents amyloid beta-peptide fibril formation and neurotoxicity. Neuroreport18:813-816.
North J, Ndakidemi P, Laubscher C (2012) Effects of antioxidants, plant growth regulators and wounding on phenolic compound excretion during micropropagation of Strelitzia reginae. International Journal of the Physical Science7 : 638-646. DOI: http://dx.doi.org/10.5897/IJPS11.786.

Pattnaik SK, Chand PK (1997) Rapid clonal propagation of three mulberries, Morus cathayana Hemsl., Morus ihou Koidz and Morus serrate Roxb., through in vitro culture of apical shoot buds and nodal explants from mature trees. Plant Cell Reports 16:503508. doi: 10.1007/BF01092774.

Peixe A, Calado J, Carlos R (2015)A one-step procedure for in vitro micro propagation of stevia (Stevia Rebaudiana). Acta Horticulturae 1083:295-301. doi: 10.17660/ActaHortic.2015.1083.37.

Phiny C, Preston TR, Ly J (2003) Mulberry (Morus alba) leaves as protein source for young pigs fed rice-based diets: Digestibility studies. Livestock Research for Rural Development 15 :1-11.

Raghunath MK, Karaba N, Nataraja, Meghana JS, Sajeevan RS, Rajan MV, Qadri SMH (2013) In vitro plant regeneration of Morus indica L. cv. V1 using leaf explant. American Journal of Plant Sciences 4: 2001-2005. DOI: http://dx.doi.org/10.4236/ajps.2013.410249.

Rahmathulla_VK (2012) Management of climatic factors for successful silkworm (Bombyx mori L.) crop and higher silk production: A review. A Journal of Entomology Article ID 121234:1-12. doi:10.1155/2012/121234.

Rohela GK, Prasad B, Srinivas K, Sadanandam A, Ravi CH, Christopher RT(2013) In vitro plantlet regeneration from leaf and stem calluses of Rauwolfia tetraphylla ( $R$. canescens) and confirmation of genetic fidelity of plantlets using the ISSR-PCR method. Journal of Herbs, Spices \& Medicinal Plants 19:66-75. doi:10.1080/10496475.2012.741056.

Rohela GK, Prasad B, Ravi CH, Rajender K, Christopher RT (2015) In vitro clonal propagation of Rauwolfia tetraphylla, a relative of indian snake root plant. Research Journal of Biotechnology $10: 23-31$.

Rohela GK, Bylla P, Korra R, Reuben C (2016a) Phytochemical screening and antimicrobial activity of leaf, stem, root and their callus extracts in Rauwolfia tetraphylla. International Journal of Agriculture \& Biology 18:21-528. doi: 10.17957/IJAB/15.0120.

Rohela GK, Pawan S, Ravindra MA, Mudasir G, Aftab AS, Srinivasulu Y, Sharma SP(2016b) Somatic Hybridization as a Potential Tool for Mulberry Improvement: A Review. Indian Horticulture Journal 6(Special): 46-49. 
Rohela GK, Santhosh D, Prasad B, Rajender K, Sreenu P, Christopher TC (2016c) Somatic embryogenesis and indirect regeneration in Mirabilis jalapa Linn. Materials Today: Proceedings 3 3: 3882-3891. DOI: https://doi.org/10.1016/j.matpr.2016.11.045.

Rohela GK, Phanikanth J, Aftab AA, Pawan S, Sadanandam A, Mrinal KG (2018a) In vitro regeneration and assessment of genetic fidelity of acclimated plantlets by using ISSR markers in PPR-1 (Morus sp.): An economically important plant. Scientia Horticultura 241: 313-321. DOI: https://doi.org/10.1016/j.scienta.2018.07.012.

Rohela GK, Aftab AS, Pawan S, Ravindra A, Mudasir G, Srinivasulu Y, Sharma SP (2018b) In vitro clonal propagation of PPR-1, a superior temperate mulberry variety. Indian Journal of Biotechnology 17: October 2018:619-625.

Sajeevan RS, Jeba SS, Karaba N, Shivanna B (2011) An efficient in vitro protocol for multiple shoot induction in mulberry, Morus $a l b a \mathrm{~L}$ variety V1. International Research Journal of Plant Science $2: 254-261$

Sanchez MD (2002) World distribution and utilization of mulberry and its potential for animal feeding.FAO Animal production and health paper. FAO corporate document repository, Rome, Italy, Pp. 345. Available on http://www.fao.org/docrep/005/x9895E/x9895e02.htm access on 25th April, 2018.

Sanchez MD (2000) Mulberry: an exceptional forage available almost worldwide. World Animal Review 93: 1-21.

Shabir AW, Malik GN, Mir MR, Parveez G, Naina M, Ashraf BM (2014) Evaluation of mulberry germplasm based on leaf and yield parameters. The Bioscan $9: 1399-1404$.

Shankar MA, Rajegowda, Jayaramaiah M, Rangaswamy BT, Maibaum W(2001) Response of mulberry to nitrogen and sulphate of potash on yield and quality of leaf, in relation to sustainable cocoon production and grainage parameters. Plant Nutrition 92: 326-327. doi: 10.1007/0-306-47624-x_157.

Shukla P, Gulab KR, Aftab AS, Sharma SP (2016) Prospect of Cold Tolerant Genes and Its Utilization in Mulberry
Improvement. Indian Horticulture Journal 6(Special): 127-129.

Silvia V, Adriana S, Luis M (2002)Plant regeneration from shoot apical meristems of Melia azedarach L. (Meliaceae). Acta Physiologiae Plantarum 24 : 195-199.

Srivastava S, Kapoor R, Thathola A, Srivastava RP (2006) Nutritional quality of leaves of some genotypes of mulberry (Morus alba). International Journal of Food Sciences and Nutrition 57 : 305-13.doi: 10.1080/09637480600801837.

Sujatha D, Ravi CH, Raghuvardhan L, Prasad B, Gulab Khan R, Sadanandam A, Christopher RT (2013) In vitro plantlet regeneration and genetic transformation of sponge gourd (Luffa cylindrica L.) African Journal of Plant Sciences 7 :244-252. doi: 10.5897/AJPS12.196.

Sujatha G, Jayabalan N, Ranjitha Kumari BD (2007) Rapid in vitro micro propagation of Cicerarietinum L. Horticultural Sciences (Prague) $34: 1-5$.

Thomas DT (2002) Advances in mulberry tissue culture. Journal of Plant Biology 45:7. doi: 10.1007/BF03030427.

Vijayan K (2010)The emerging role of genomic tools in mulberry (Morus) genetic improvement. Tree Genetics \& Genomes 6 : 613-625. doi: 10.1007/s11295-010-0276-z.

Vijayan K, Chakraborti SP, Roy BN (2000) Plant regeneration from leaf explants of mulberry: influence of sugar, genotype and 6benzyladenine. Indian Journal of Experimental Biology 38: 504 - 508.

Vijayan K, Chauhan S, Das NK, Chakraborti SP, Roy BN (1997b) Leaf yield component combining abilities in mulberry (Morus spp.), Euphytica 98 : 47-52. doi: 10.1023/A:1003066613099.

Vijayan K, Tikader A, Das KK, Chakraborti SP, Roy BN (1997a) Correlation studies in mulberry (Morus spp.). Indian Journal of Genetics and Plant breeding 57: 455-460.

Vineet K, Javuli K, Mala VR (2012) Leaf and anatomical traits in relation to physiological characteristics in mulberry (Morus sp.) cultivars. Turkish Journal of Botany 36: 683-689. doi:10.3906/bot-1003-48. 